\title{
ANALISIS PENERAPAN PSAK NO. 45 TENTANG PELAPORAN KEUANGAN ENTITAS NIRLABA PADA JEMAAT GMIST PNIEL BIAU KAB, KEP. SITARO
}

\author{
Raisa Stephanie Janis ${ }^{1}$, Novi S. Budiarso ${ }^{2}$ \\ ${ }^{1}$ Pendidikan Profesi Akuntansi, Fakultas Ekonomi dan Bisnis, Universitas Sam Ratulangi, Jl. Kampus Bahu, \\ Manado, 95115, Indonesia \\ ${ }^{2}$ Pendidikan Profesi Akuntansi, Fakultas Ekonomi dan Bisnis, Universitas Sam Ratulangi, Jl. Kampus Bahu, \\ Manado, 95115, Indonesia \\ E-mail : raisajanis260@yahoo.co.id
}

\begin{abstract}
Profit entity is an organization that can be owned by the government or private sector owned, its main purpose is not for profit. One nonprofit entity engaged in religious church. As a nonprofit entity, the church should make financial statements accountability and reporting to users of financial statements of the church, the church that is the main source of income in the church. In Indonesia, a special standard financial reporting profit entity organized under Statement of Financial Accounting Standards (SFAS) No. 45. This research was conducted at the Jemaat GMIST Pniel Biau. The purpose of this study was to determine the adoption of PSAK No. 45 of the Financial Reporting Entities Non-Profit on Jemaat GMIST Pniel Biau. Descriptive qualitative analysis method is a method discussion of issues that are outlining, describe, compare and explain the data. Results showed Jemaat GMIST Pniel Biau not yet adopted PSAK No. 45 on the presentation of its financial statements, but the church is preparing financial statements of the realization of revenues and expenditures in accordance with the regulations GMIST no. 6 in 2012.
\end{abstract}

Keywords : PSAK No. 45, non profit, financial statements

\section{PENDAHULUAN}

Istilah organisasi berasal dari bahasa Yunani "organ" yang berarti "alat". Dalam pengertian umum, organisasi dapat dipahami sebagai alat atau wadah sekelompok orang yang berkumpul dan bekerja sama dengan cara yang terstruktur untuk mencapai tujuan atau sejumlah sasaran tertentu yang telah ditetapkan bersama (Mahsun, dkk 2011: 1). Entitas nirlaba adalah organisasi yang dapat dimiliki pemerintah maupun dimiliki sektor swasta, tujuan utamanya tidak untuk mendapatkan keuntungan. Entitas nirlaba memperoleh sumber daya dari sumbangan para anggota dan para penyumbang lain yang tidak mengharapkan imbalan kembali.

Tujuan penyajian laporan keuangan adalah memberikan informasi yang digunakan dalam pengambilan keputusan digunakan sebagai bentuk pertanggungjawaban pemegang organisasi dan evaluasi kinerja pimpinan organisasi. (Sujarweni 2015:5). Laporan keuangan sangat penting bagi perusahaan swasta maupun entitas nirlaba. PSAK 45 terdiri dari Laporan posisi keuangan, Laporan aktivitas, Laporan Arus kas, dan CALK.

Salah satu entitas nirlaba yang bergerak dibidang keagamaan yaitu Gereja. Salah satunya Jemaat GMIST Pniel Biau. Tugas gereja bukan hanya sekedar melayani tetapi juga mendukung aspek-aspek lain termasuk di dalamnya laporan keuangan yang pencatatannya tidak hanya dilakukan secara tradisional yaitu masuk keluar kas tanpa adanya pelaporan yang akurat. Untuk mengatasi masalah dalam pengelolaan keuangan gereja serta memberikan suatu pertanggungjawaban dan akuntabilitas kepada jemaat sebagai sumber utama pendapatan maka gereja harus menyusun laporan keuangan yang sesuai dengan aturan atau standar pelaporan yang telah diatur dalam PSAK No. 45 agar laporan keuangan gereja dapat 
lebih mudah dipahami, memiliki relevansi dan memiliki daya banding yang tinggi. Berdasarkan latar belakang maka topik dalam penelitan ini adalah " Analisis Penerapan PSAK No. 45 tentang Pelaporan Keuangan Entitas Nirlaba pada GMIST Jemaat Pniel Biau”.

\section{TINJAUAN PUSTAKA}

2.1. Pengertian Akuntansi

Deddi, Iswahyudi, Maulidah (2012: 1) menyatakan akuntansi merupakan proses mengenali, mengukur, dan mengkomunikasikan informasi ekonomi untuk memperoleh pertimbangan dan keputusan yang tepat oleh pemakai informasi yang bersangkutan.

\subsection{Tujuan Laporan Keuangan}

Tujuan laporan keuangan adalah untuk memberikan informasi kepada pihak yang membutuhkan tentang kondisi suatu perusahaan dari sudut angka-angka dalam satuan moneter (Fahmi, 2014: 26).

\subsection{Entitas Nirlaba}

Korompis (2014: 54) Organisasi nirlaba atau organisasi non profit adalah suatu organisasi yang bersasaran pokok untuk mendukung suatu isu atau perihal di dalam menarik perhatian publik untuk suatu tujuan yang tidak komersil, tanpa ada perhatian terhadap hal-hal yang bersifat mencari laba (moneter).

\subsection{Konsep PSAK No. 45 tentang Pelaporan Keuangan Entitas Nirlaba}

\subsubsection{Karakteristik Entitas Nirlaba}

IAI (2015: 45.2-45.3) karakteristik entitas nirlaba yaitu sebagai berikut:

1. Sumber daya entitas nirlaba berasal dari pemberi sumber daya yang tidak mengharapkan pembayaran kembali atau manfaat ekonomi yang sebanding dengan jumlah sumber daya yang diberikan.

2. Menghasilkan barang dan/atau jasa tanpa bertujuan menumpuk laba, dan jika entitas nirlaba menghasilkan laba, maka jumlahnya tidak dibagikan kepada para pendiri atau pemilik entitas tersebut.

3. Tidak ada kepemilikan seperti umumnya pada entitas bisnis, dalam arti bahwa kepemilikan dalam entitas nirlaba tidak dapat dijual, dialihkan, atau ditebus kembali, atau kepemilikan tersebut tidak mencerminkan proporsi pembagian sumber daya entitas pada saat likuidasi atau pembubaran entitas nirlaba.

\subsubsection{Tujuan Laporan Keuangan Entitas Nirlaba}

IAI (2015: 45.3) dalam PSAK No. 45 menyatakan bahwa "Tujuan utama Iaporan keuangan adalah menyediakan informasi yang relevan untuk memenuhi kepentingan para pemberi sumber daya yang tidak mengharapkan pembayaran kembali, anggota, kreditor, dan pihak lain yang menyediakan sumber daya bagi entitas nirlaba”.

\subsubsection{Jenis-jenis Laporan Keuangan Entitas Nirlaba}

Unsur-unsur laporan keuangan berdasarkan PSAK No. 45 :

1. Laporan Posisi Keuangan

Laporan posisi keuangan mencakup entitas nirlaba secara keseluruhan dan menyajikan total aset, liabilitas, dan aset neto.

2. Laporan Aktivitas

Laporan aktivitas mencakup entitas nirlaba secara keseluruhan dan menyajikan perubahan jumlah aset neto selama suatu periode.

3. Laporan Arus Kas

Laporan arus kas harus melaporkan arus kas selama periode tertentu dan diklasifikasi menurut aktivitas operasi,investasi, dan pendanaan.

4. Catatan Atas Laporan Keuangan

Catatan atas laporan keuangan dapat berupa:

a. Perincian dari suatu perkiraan yang disajikan, misalnya aktiva tetap; 
b. Kebijakan akuntansi yang dilakukan, misalnya metode penyusutan serta tarif yang digunakan untuk aktiva tetap lembaga, metode pencatatan piutang yang tidak dapat ditagih serta presentase yang digunakan untuk pencadangannya.

\subsubsection{Regulasi Entitas Nirlaba (Gereja Masehi Injili di Sangihe-Talaud)}

Pada gereja protestan khususnya Gereja Masehi Injili di Sangihe dan Talaud (GMIST) ada regulasi yang mengatur seluruh aktivitas maupun pelaporan pada gereja-gereja GMIST, yang tertuang dalam Peraturan GMIST Nomor 6 Tahun 2012 tentang Keuangan dan Perbendaharaan GMIST.

\subsection{Penelitian Terdahulu}

Wahyu Repi (2015) melakukan penelitian berjudul Analisis Penerapan PSAK NO. 45 (Revisi 2011) Tentang Pelaporan Keuangan Entitas Nirlaba Pada STIKES Muhammadiyah Manado. Hasil penelitian menunjukkan bahwa STIKES Muhammadiyah Manado belum menyusun laporan keuangan sesuai PSAK No. 45.laporan keuangan STIKES hanya berupa neraca saldo, sehingga untuk itu dilakukan pembuatan laporan posisi keuangan, laporan aktivitas, laporan arus kas dan catatan atas laporan keuangan.

Ronny Hendrawan (2011) melakukan penelitian berjudul Analisis Penerapan PSAK No. 45 tentang Pelaporan Keuangan Organisasi nirlaba pada Rumah Sakit Berstatus Badan Layanan Umum di RSUD Kota Semarang. Hasil penelitian menunjukkan tidak ada perbedaan dalam perhitungan antara laporan keuangan BLU RUSD Kota Semarang dengan PSAK No. 45. PSAK No. 45 dapat diterapkan secara penuh dalam laporan keuangan BLU khususnya rumah sakit.

\section{METODE PENELITIAN}

\subsection{Jenis Penelitian}

Jenis penelitian ini adalah penelitian kualitatif yang menghasilkan penemuanpenemuan yang tidak dapat dicapai dengan menggunakan prosedur-prosedur statistik atau dengan cara kuantifikasi lainnya. Menurut Sugiyono (2010: 18), jenis-jenis metode penelitian dikelompokkan berdasarkan tujuan, dan tingkat kealamiahan (natural setting) obyek yang diteliti.

\subsection{Tempat dan Waktu Penelitian}

Tempat penelitian ini dilakukan di GMIST Pniel Biau yang terletak di Kampung Biau Kecamatan Siau Timur Selatan Kabupaten Kepulauan SITARO, Sulawesi Utara. Adapun waktu penelitian dimulai dari bulan April 2016 sampai dengan selesai.

\subsection{Jenis Data}

Jenis data yang digunakan dalam penelitian ini berupa data kualitatif berupa hasil wawancara dan kuantitatif berupa laporan keuangan.

\subsection{Metode Analisis Data}

Dalam penelitian ini, penulis menggunakan metode penelitian kualitatif deskriptif. Dimana, analisis data yang digunakan menggunakan metode analisis kualitatif deskriptif yaitu suatu metode pembahasan permasalahan yang sifatnya menguraikan, menggambarkan, membandingkan dan menerangkan suatu data. Penulis mengumpulkan data kuantitatif dan kualitatif lewat wawancara maupun hasil dokumentasi, mempelajari laporan-laporan apa saja yang dibuat dalam gereja, serta kebijakan atau regulasi yang ada dalam gereja. Kemudian, membandingkan hasil yang didapatkan dari objek penelitian (gereja) dengan literatur-literatur yang dijadikan sebagai dasar acuan untuk menerapkan PSAK No.45 pada laporan keuangan organisasi nirlaba dalam hal ini GMIST Pniel Biau dan menarik kesimpulan. 


\section{HASIL ANALISIS DAN PEMBAHASAN}

\subsection{Hasil Penelitian}

\subsubsection{Laporan Keuangan}

1. Laporan keuangan Jemaat GMIST pniel Biau berupa anggaran pendapatan dan belanja dan laporan realisasi anggaran.

2. Laporan keuangan dilaporkan kepada jemaat melalui warta jemaat setiap hari minggu.

3. Anggaran pendapatan dan belanja jemaat disusun oleh BPMJ dan menyampaikan rancangan APBJ dalam sidang tahunan majelis jemaat.

4. Rencana anggaran pendapatan dan belanja jemaat disusun awal tahun dan dibandingkan hasilnya pada realisasi anggaran akhir tahun.

\subsubsection{Penyajian Laporan Keuangan Jemaat GMIST Pniel Biau}

Semua penerimaan dan pengeluaran keuangan jemaat dicatat dalam buku kas umum kemudian dari buku kas umum tersebut bendahara menyusun laporan realisasi anggaran pendapatan dan belanja satu tahun berjalan dan dapat dipertanggungjawabkan dalam sidang tahunan majelis jemaat. Hal ini berarti Jemaat GMIST Pniel Biau belum menerapkan PSAK No. 45 tentang pelaporan keuangan entitas nirlaba pada penyajian laporan keuangannya.

\subsection{Pembahasan}

\subsubsection{Penyajian Laporan Posisi Keuangan menurut PSAK No. 45}

Aset. Kas dan setara kas yang disajikkan dalam laporan posisi keuangan tahun 2015 merupakan total atau jumlah dari asset neto pada akhir tahun. Aset lancar untuk Jemaat GMIST Pniel Biau hanya terdiri dari kas dan setara kas karena Jemaat GMIST Pniel Biau tidak memiliki piutang dan persediaan. Sedangkan untuk aset tidak lancar seperti aset tetap dan inventaris gereja, laporannya hanya berupa jumlah unit yang disusun dalam daftar inventarisasi gereja sehingga tidak diketahui nilai buku dari aset tetap dan perlengkapan.

Liabilitas dan Aset Neto. Jemaat GMIST Pniel Biau tidak memiliki saldo liabilitas pada akhir tahun 2015. Aset neto Jemaat GMIST Pniel Biau terdiri dari Aset Neto Terikat dan Aset Neto Terikat Temporer. Nilai Aset Neto Terikat Temporer dalam laporan posisi keuangan 2015 merupakan saldo akhir yang merupakan hasil dari perhitungan sumber daya terikat dikurangi penggunaan untuk biaya-biaya sesuai pembatasan dalam periode laporan, perhitungannya disajikan dalam catatan atas laporan keuangan. Sedangkan untuk nilai aset neto tidak terikat yang disajikan dalam laporan posisi keuangan tahun 2015 merupakan hasil perhitungan jumlah pendapatan dan penghasilan tidak terikat dikurangi jumlah beban dan pengeluaran. Berdasarkan hasil perhitungan yang diperoleh, sumber daya tidak terikat tahun 2015 tidak dapat memenuhi kebutuhan dana untuk biaya dan kewajiban yang tidak termasuk dalam pembatasan, dan nilai tersebut oleh Jemaat GMIST Pniel Biau dpenuhi dengan sumber daya terikat temporer. 
Tabel 1. Laporan Posisi Keuangan Tahun 2015

GMIST PNIEL BIAU

LAPORAN POSISI KEUANGAN

UNTUK TAHUN YANG BERAKHIR

31 DESEMBER 2015

(Disajikan dalam Rupiah penuh)

\section{ASET}

ASET LANCAR

Kas dan Setara Kas

ASET TIDAK LANCAR

Aset Tidak Lancar

TOTAL ASET

\section{LIABILITAS DAN ASET BERSIH}

LIABIITAS JANGKA PENDEK

Hutang

JUMLAH LIABILITAS JANGKA PENDEK

LIABILITAS JANGKA PANJANG

Hutang Lain-lain Jangka Panjang

JUMLAH LIABILITAS JANGKA PANJANG

TOTAL LIABILITAS

ASET NETO

Aset Neto Tidak Terikat

Aset Neto Terikat Temporer

JUMLAH LIABILITAS DAN ASET BERSIH

Sumber Data Olahan 2015

\subsubsection{Penyajian Laporan Aktivitas menurut PSAK No. 45}

Pendapatan. Dalam laporan aktivitas tahun 2015, pendapatan terbagi atas dua yaitu pendatapan jasa layanan dan pendapatan lain-lain. Untuk pendapatan jasa layanan, nilai yang disajikan merupakan pendapatan yang diperoleh saat gereja memberikan jasa pelayanan yaitu persembahan. Sedangkan untuk pendapatan lain-lain merupakan persembahan perpuluhan yang bersumber dari hasil panern anggota jemaat.

Aset Neto yang Berakhir Pembatasannya. Pemenuhan program pembatasan yang termasuk dalam aset neto yang berakhir pembatasannya pada tahun 2015 merupakan total aset yang dikeluarkan untuk program pembatasan, nilai ini juga secara langsung merupakan jumlah aset yang pembatasannya telah berakhir karena telah digunakan untuk pemenuhan program yang telah dibatasi. Perhitungannya dapat dilihat dalam Catatan $\mathrm{C}$ di Catatan Atas Laporan Keuangan.

Jumlah Pendapatan. Jumlah pendapatan pada tahun 2015 merupakan total dari penjumlahan aset neto yang berakhir pembatasannya dengan jumlah dari pendapatan.

Beban. Yang termasuk dalam beban pada tahun 2015 yaitu semua penggunaan dana untuk membiayai program disetiap bidang, operasional gereja, tunjangan-tunjangan, dan pelunasan kewajiban ke Sinode, subsidi ke SD YPK, dan lain-lain.

Perubahan Aset Neto Terikat Temporer. Perubahan aset neto terikat temporer adalah total sumber daya terikat dan asset neto yang terbebaskan oleh pembatasan. 
Tabel 2. Laporan Aktivitas Tahun 2015

\section{GMIST PNIEL BIAU}

LAPORAN AKTIVITAS

UNTUK TAHUN YANG BERAKHIR

31 DESEMBER 2015

(Disajikan dalam Rupiah penuh)

\begin{tabular}{|c|c|}
\hline \multicolumn{2}{|c|}{$\begin{array}{l}\text { PERUBAHAN ASET NETO TIDAK TERIKAT } \\
\text { Pendapatan }\end{array}$} \\
\hline Sumbangan & - \\
\hline Jasa Layanan & $306,033,000$ \\
\hline Penghasilan dari Investasi & - \\
\hline Lain-lain & $44,744,000$ \\
\hline Jumlah & $350,777,000$ \\
\hline \multicolumn{2}{|c|}{ Aset Neto yang Berakhir Pembatasannya (Catatan C): } \\
\hline Pemenuhan Program Pembatasan & $32,150,000$ \\
\hline Jumlah & $32,150,000$ \\
\hline Jumlah Pendapatan & $382,927,000$ \\
\hline \multicolumn{2}{|c|}{ Beban : } \\
\hline Biaya Petugas Ibadah & $39,575,000$ \\
\hline Beban Diakonia & $32,150,000$ \\
\hline Beban Lain-lain & $67,769,000$ \\
\hline Beban Perlengkapan & $32,213,000$ \\
\hline Beban Tunjangan & $68,600,000$ \\
\hline Beban Listrik & $5,551,000$ \\
\hline Biaya Konsumsi & $2,652,000$ \\
\hline Biaya Sidang, Rapat, Konsultasi dan Konven & $10,758,000$ \\
\hline Biaya Laundry & 886,000 \\
\hline Biaya Pemeliharaan & $1,166,000$ \\
\hline Sentralisasi ke Sinode & $98,451,000$ \\
\hline Subsidi ke SD YPK & $2,400,000$ \\
\hline Biaya Transportasi & $2,205,000$ \\
\hline Renovasi Gereja & $60,000,000$ \\
\hline Jumlah Beban & $424,376,000$ \\
\hline Penurunan Aset Neto Tidak Terikat & $(41,449,000)$ \\
\hline \multicolumn{2}{|c|}{ PENURUNAN ASET NETO TERIKAT TEMPORER : } \\
\hline Sumbangan & $89,093,000$ \\
\hline Aset Bersih terbebaskan dari pembatasan & $32,150,000$ \\
\hline Kenaikan Aset Neto Terikat Temporer & $56,943,000$ \\
\hline Kenaikan Aset Neto & $15,494,000$ \\
\hline Aset Neto Awal Tahun & $4,886,945$ \\
\hline Aset Neto Akhir Tahun & $20,380,945$ \\
\hline
\end{tabular}

Sumber: Data Olahan 2015

\subsubsection{Penyajian Laporan Arus Kas Menurut PSAK No. 45}

Aktivitas Operasi. Perkiraan yang termasuk dalam aktivitas operasi pada laporan arus kas tahun 2015 adalah penerimaan dan pengeluaran kas yang terjadi pada perkiraan yang terkait dengan operasional gereja seperti biaya-biaya dan tunjangan-tunjangan.

Aktivitas Investasi. Perkiraan yang termasuk dalam aktivitas investasi pada laporan arus kas tahun 2015 adalah penerimaan dan pengeluaran yang terkait dengan investasi gereja. Jemaat GMIST Pniel Biau tidak terjadi aktivitas investasi untuk tahun 2015. 
Aktivitas Pendanaan. Perkiraan yang termasuk dalam aktivitas pendanaan pada laporan arus kas tahun 2015 adalah perkiraan penerimaan kas dari kontribusi jemaat yang penggunaannya dibatasi, dan pengeluaran kas seperti pelunasan kewajiban aktivitas pendanaan lain.

Tabel 4. Laporan Arus Kas tahun 2015
GMIST PNIEL BIAU
LAPORAN ARUS KAS
UNTUK TAHUN YANG BERAKHIR
31 DESEMBER 2015
(Disajikan dalam Rupiah penuh)

\begin{tabular}{|c|c|}
\hline \multicolumn{2}{|l|}{ AKTIVITAS OPERASI } \\
\hline Kas dari Jasa Layanan & $306,033,000$ \\
\hline \multirow[t]{2}{*}{ Penerimaan Lain-lain } & $44,744,000$ \\
\hline & $350,777,000$ \\
\hline Biaya Petugas Ibadah & $39,575,000$ \\
\hline Beban Lain-lain & $67,769,000$ \\
\hline Beban Perlengkapan & $32,213,000$ \\
\hline Beban Tunjangan & $68,600,000$ \\
\hline Beban Listrik & $5,551,000$ \\
\hline Biaya Konsumsi & $2,652,000$ \\
\hline Biaya Sidang, Rapat, Konsultasi, dan Konven & $10,758,000$ \\
\hline Biaya Laundry & 886,000 \\
\hline Biaya Pemeliharaan & $1,166,000$ \\
\hline Biaya Transportasi & $2,205,000$ \\
\hline \multirow[t]{2}{*}{ Renovasi Gereja } & $60,000,000$ \\
\hline & $291,375,000$ \\
\hline Kas neto yang diterima (digunakan) untuk aktivitas operasi & $59,402,000$ \\
\hline \multicolumn{2}{|l|}{ AKTIVITAS INVESTASI } \\
\hline \multirow{2}{*}{\multicolumn{2}{|c|}{$\begin{array}{l}\text { Penerimaan dari Investasi } \\
\text { Kas neto yang diterima (digunakan) untuk aktivitas investasi }\end{array}$}} \\
\hline & \\
\hline \multicolumn{2}{|l|}{ AKTIVITAS PENDANAAN } \\
\hline \multicolumn{2}{|l|}{ Penerimaan dari kontribusi berbatas dari: } \\
\hline Pundi Khusus & $58,068,000$ \\
\hline Kotak Pelayanan & $6,814,000$ \\
\hline \multirow[t]{2}{*}{ Kotak Sukarela } & $24,211,000$ \\
\hline & $89,093,000$ \\
\hline \multicolumn{2}{|l|}{ Aktivitas Pendanaan Lain: } \\
\hline Sentralisasi ke Sinode & $98,451,000$ \\
\hline Subsidi ke SD YPK & $2,400,000$ \\
\hline \multirow[t]{2}{*}{ Diakonia } & $32,150,000$ \\
\hline & $\begin{array}{l}133,001,000 \\
(\mathbf{4 3 , 9 0 8 . 0 0 0 )}\end{array}$ \\
\hline KENAIKAN NETO DALAM KAS DAN SETARA KAS & $15,494,000$ \\
\hline KAS DAN SETARA KAS PADA AWAL TAHUN & $\mathbf{4 , 8 8 6 , 9 4 5}$ \\
\hline KAS DAN SETARA KAS AKHIR TAHUN & $20,380,945$ \\
\hline
\end{tabular}

Sumber: Data Olahan 2015 


\section{Catatan Atas Laporan Keuangan}

Catatan Atas Laporan Keuangan Jemaat GMIST Pniel Biau yaitu:

a. Kebijakan Badan Pekerja Majelis Jemaat GMIST Pniel Biau

b. Catatan Aset Bersih Terikat Temporer

c. Catatan Aset Bersih yang dibebaskan dari pembatasan

\section{Tabel 5. Catatan Atas Laporan Keuangan}

\section{Jemaat GMIST Pniel Biau}

\section{Catatan Atas Laporan Keuangan 2015}

Catatan A menguraikan kebijakan gereja yang menyebabkan catatan B dan $\mathrm{C}$ disajikan.

Catatan A

Jemaat GMIST Pniel Biau menyajikan sumbangan terikat dalam tiga akun yaitu, Sentralisasi ke Sinode, Subsidi ke SD YPK dan Diakonia. Jika kebutuhan untuk tiga akun tersebut telah terpenuhi, maka dana-dana tersebut dapat digunakan untuk pembiayaan aktivitas lain gereja. Apabila sumbangan Sentralisasi ke Sinode, Subsidi ke SD YPK, dan Diakonia tidak cukup membiayai kebutuhan Sentralisasi ke Sinode, Subsidi ke SD YPK dan Diakonia maka kebutuhan dana tersebut dipenuhi dengan menggunakan dana dari kas.

Catatan B

Sentralisasi ke Sinode

Kotak Pelayanan

Sentralisasi

Subsidi ke SD YPK

Kotak Pelayanan

Subsidi

Diakonia

Kotak Sukarela

Diakonia Sakit

Diakonia Duka

Diakonia Lansia
Rp 58,068,000

$\underline{(\mathrm{Rp} 98,451,000)}$

(Rp 40,383,000)

$$
\begin{array}{lr}
\mathrm{Rp} & 6,814,000 \\
\mathrm{Rp} & 2,400,000 \\
\hline
\end{array}
$$

Rp 4,414,000

$$
\begin{aligned}
& \operatorname{Rp} 24,211,000 \\
& \operatorname{Rp} 16,075,000 \\
& \operatorname{Rp} 12,875,000 \\
& \operatorname{Rp} 3,200,000 \\
& \operatorname{Rp} 32,150,000 \\
& \hline
\end{aligned}
$$

Total Aset Terikat

Kegiatan Lain-lain Gereja

Aset Neto Terikat Temporer

Catatan C

Asset neto yang dibebaskan dari pemberi sumber daya yang tidak mengharapkan pembayaran kembali melalui terjadinya beban tertentu atau terjadinya kondisi yang diisyratkan oleh pemberi sumber daya yang tidak mengharapkan pembayaran kembali:

Tujuan pembatasan yang dicapai:

Diakonia

$\operatorname{Rp} 32,150,000$

Pembatasan yang telah terpenuhi

$$
\begin{gathered}
(\operatorname{Rp} 7,939,000) \\
\hline \operatorname{Rp} 43,908,000 \\
\operatorname{Rp} 59,402,000 \\
\hline \operatorname{Rp} 15,494,000
\end{gathered}
$$

Sumber: Data Olahan 2015 


\section{KESIMPULAN DAN SARAN}

\subsection{Kesimpulan}

1. GMIST Jemaat Pniel Biau belum menerapkan PSAK no. 45 pada penyajian laporan keuangannya. Jemaat GMIST Pniel Biau hanya menyusun laporan keuangan berupa laporan realisasi anggaran pendapatan dan belanja sesuai dengan peraturan GMIST no. 6 tahun 2012.

2. Jemaat GMIST Pniel Biau belum melakukan penilaian dan pengungkapan terhadap aset tetap, tapi hanya mencatatnya dalam daftar inventaris.

3. Meski belum menyajikan laporan keuangan sesuai PSAK No. 45 tapi Jemaat GMIST Pniel Biau telah menerbitkan laporan realisasi anggaran pendapatan dan belanja serta mempunyai Badan Pengawas Program dan Perbendaharaan yang merupakan bentuk pertanggungjawaban dan transparansi pengelolaan keuangan.

\subsection{Saran}

1. Sebaiknya Jemaat GMIST Pniel Biau menerapkan PSAK No. 45 dalam penyajian laporan keuangannya sehingga dapat menghasilkan laporan keuangan yang berkualitas.

2. Sebaiknya Jemaat GMIST Pniel Biau ketika membeli suatu aset tetap tidak hanya mencatatnya dalam buku inventaris gereja tapi menyajikan harga dan tahun perolehannya agar dapat dilakukan penyusutan terhadap aset tetap sehingga dapat diketahui nilai buku dan masa manfaatnya serta disajikan dalam laporan posisi keuangan.

\section{DAFTAR PUSTAKA}

Deddi, Iswahyudi, Maulidah, 2012. Akuntansi Pemerintahan. Salemba Empat. Jakarta.

Fahmi, Irham. 2014. Analisis Kinerja Keuangan. Alfabeta. Bandung.

Hery. 2013. Teori Akuntansi - Suatu Pengantar. Lembaga Penerbit Fakultas Ekonomi Universitas Indonesia. Jakarta.

Ikatan Akuntan Indonesia. 2015. Pernyataan Standar Akuntansi Keuangan No. 45 (Revisi 2015 ) Pelaporan Keuangan Entitas Nirlaba. Jakarta.

Korompis, Cwm. 2014. Penerapan PSAK No. 45 Tentang Pelaporan Keuangan Organisasi Nirlaba pada Sanggar Seni Budaya Logos Ma'Kantar.

Mahsun, Sulistiyowati, Purwanugraha. 2011. Akuntansi Sektor Publik. BPFE. Yogyakarta.

Repi, Wahyu. 2015. Analisis Penerapan PSAK No. 45 (Revisi 2011) tentang Pelaporan Keuangan Entitas Nirlaba pada STIKES Muhammadiyah. Universitas Sam Ratulangi. Manado.

Ronny, Hendrawan. 2011. Analisis Penerapan PSAK No. 45 Tentang Pelaporan Keuangan Organisasi Nirlaba pada Rumah Sakit Berstatus Badan Layanan Umum. Universitas Diponegoro. Semarang.

Sujarweni. 2015. Akuntansi Sektor Publik. Pustaka Baru Press. Yogyakarta.

Sugiyono. 2010. Metode Penelitian Kuantitatif, Kualitatif dan R\&D. Alfabeta. Bandung. 